\title{
GENEALOGI PETILASAN SUNAN KUDUS
}

\author{
Genealogy of Sunan Kudus's 'Petilasan'
}

\author{
Mas'udi \\ Sekolah Tinggi Agama Islam Negeri Kudus \\ Jl. Conge Ngembalrejo PO BOX. 51 Kudus. 59322 \\ Email: msd.jufri@gmail.com
}

Naskah diterima tanggal 19 Juli 2013. Naskah direvisi tanggal 31 Juli 2013. Naskah disetujui tanggal 15 Agustus 2013

\begin{abstract}
Abstrak
Raden Ja'far Shodiq, Sunan Kudus dalam usaha memasyarakatkan Islam ke seluruh pelosok Kudus, tidak hanya menempatkan sentralitas penyiaran agama di kawasan Kauman tempat berdirinya Masjid al-Aqsha atau Masjid Menara Kudus. Salah satu tempat didirikannya masjid luar dari kawasan Kauman adalah Masjid Wali Al-Mảmur Desa Jepang Kecamatan Mejobo Kabupaten Kudus. Penelitian ini termasuk penelitian sejarah sosial bersifat kualitatif. metode pengumpulan data dilakukan secara heuristik, interpretasi, kritik sumber, dan historiografi. Sumber datanya adalah sumber tertulis, material, dan lisan. Penelitian ini dilangsungkan mulai Februari 2012 sampai Juli 2012. Hasil penelitian ini menemukan bahwa Masjid Wali Al-Ma’mur Desa Jepang memiliki keterhubungan sejarah dengan Masjid Menara Kudus yang pembangunannya bertarikh tahun 956 H (1549 M). Realitas ini tampak dari kesamaan tata ruang yang mengitari Masjid Wali Al-Mảmur Desa Jepang. Peletakan Gapura di bagian depan masjid dan makam para tokoh masyarakat di zamannya diletakkan di belakang masjid serupa dengan ditempatkannya makam Sunan Kudus di belakang Mesjid Menara Kudus.
\end{abstract}

Kata kunci: masjid, keislaman, dakwah

\begin{abstract}
Raden Ja'far Shodiq, : to attempt islamic doctines at Kudus Regency, not centralized missionary endeavor in Kauman the place of Al-Aqsha Mosque building. The other place he builds outside of Al-Aqsha Mosque territory is Wali Mosque at Jepang Village Sub-district of Mejobo Kudus Regency. This research classified as social historical study by qualitative types. To collects data by, heuristic, interpretation, source criticism, and historiography. Furthermore, the sources of data are written, material, and oral resources. This research be implemented begin at February 2012 until July 2012. This research discovers Wali Mosque has really historical correlations with Menara Mosque, as dated $956 \mathrm{H}$ (1549 BC). The realities are visibling by the same space arrangements as encircle Wali Mosque. Padureksa Gate located ahead of mosque and the assignment of graves of figures lying down behind the mosque as like the lying down of: grave locating in the wake of Menara Kudus Mosque.
\end{abstract}

Keywords: mosque, islamic doctrine, and missionary endeavor

\section{PENDAHULUAN}

$\mathrm{S}$ ejarah pertumbuhan agama Islam di Kudus merupakan salah satu unsur yang mengisi keberislaman masyarakat Jawa. Pertumbuhan agama Islam yang pesat dan harmoni masyarakat yang tercipta menunjukkan keramahan penyebaran agama Islam di wilayah Kudus. Bukti lain yang dapat dianalisa sebagai kekuatan pertumbuhan agama Islam di wilayah Kudus adalah bangunan Masjid Menara Kudus yang telah dibangun pada abad ke-16 tepatnya tahun 1549 M. Harmoni daerah Kudus dengan pertumbuhan budaya keislaman masyarakatnya diapresiasi sepenuhnya oleh Lombard. Dalam karyanya ditegaskan bahwa Kota Kudus yang namanya mengacu kepada al- 
Quds (nama Arab untuk Yerussalem) merupakan kota keagamaan, kota suci, dan mempunyai masjid yang besar lagi indah (Lombard, 2005: 54).

Penyebutan Kota Kudus dengan istilah alQuds, kota suci sebagaimana disampaikan oleh Lombard terikat pula dengan guru-guru rohaniah yang membantu penguasa-penguasa Demak dalam usaha mereka menyebarkan agama Islam. Sunan Kudus merupakan tokoh sentral pengembangan keagaamaan masyarakat Kudus. Sunan Kudus bermukim di Kudus tepatnya di daerah Kauman dan mendirikanMasjid al-Aqsa atau Masjid al-Manar dan terkenal dengan nama Masjid Menara Kudus pada tahun 1549 M. MAsjid ini berbentuk unik, karena memiliki menara yang serupa bangunan candi.

Keberadaan al-Manar di bagian depan bangunan Masjid Wali Al-Ma'mur Desa Jepang Mejobo Kudusmenjadipembukti untukmenguatkan usaha-usaha SUnan Kudus menyebarkan agama Islam di desa tersebut. Perpaduan budaya lokal dengan budaya Islam dilakukan Sunan Kudus untuk menyebarkan ajaran Islam lebih harmonis dan ramah. Dijk dan Nas menjelaskan bahwa Sunan Kudus melarang penyembelihan hewan ternak (sapi) oleh para pengikutnya agar tiada menyinggung masyarakat Hindu yang terdapat di sekitarnya (Dijk dan Nas, 1998: 223). Kenyataan ini menggambarkan upaya strategis Sunan Kudus menyebarkan agama Islam dengan penuh kasih sayang (rahmatan lil'alamin) bagi masyarakat Kudus secara umum dan masyarakat Desa Jepang Mejobo Kudus secara khusus.

Berpijak asas paradigmatik pada pendahuluan di atas, maka pendekatan penelitian ini dilakukan melalui pendekatan sejarah. Mengamati pendekatan penelitian tersebut Nagazumi menjelaskan bahwa fokus kajian dalam sejarah dapat dilakukan melalui tahapan masa kemunculan tradisi masa lampau (Nagazumi, 1998: 233). Pernyataan ini disampaikan oleh Nagazumi di atas analisa yang dilakukannya dalam mengamati lintasan kesejarahan Islam Indonesia dengan awal kedatangan I'Tsing ke Nusantara. Fakta tersebut menjadi dasar pengungkapan yang akan dilakukan dalam penelitian ini berpijak kepada dasar kesejarahan Masjid Wali Al-Ma'mur Desa Jepang Mejobo Kudus. Ditinjau dari aspek arsitektur bangunannya, Masjid Wali Al-Ma’mur Desa Jepang Mejobo Kudus bersinambung dialogis dengan keberadaan Masjid Menara Kudus.

\section{Tinjauan Pustaka}

Secara umum, analisa penyebaran agama Islam yang terdapat di daerah Kudus banyak dilakukan oleh para ahli. Hal ini terlihat dari banyaknya kajian tentang genealogi wilayah Kudus terfokus pada Masjid Menara Kudus. Sri Sari Windarti (2010) dalam penelitiannya melihat bahwa Masjid Menara Kudus merupakan suatu bangunan peninggalan sejarah yang memiliki nilai arsitektur yang sangat tinggi, karena di dalamnya melibatkan banyak aspek kebudayaan di antaranya Hindu, Jawa dan Islam. Sebagai warisan budaya dari leluhur yang banyak memiliki nilai dan makna filosofis, religius dan historis menjadikan Masjid Menara Kudus sebagai salah satu obyek wisata yang terkenal di Kota Kudus.

Tinjauan kepustakaan berikutnya adalah penelitian Bambang Supriyadi (2010). Penelitian ini mengambil tema "Kajian Ornamen pada Masjid Bersejarah Kawasan Pantura Jawa Tengah". Penelitian ini mengungkapkan bahwa pemakaian ornamen pada bangunan masjid menyiratkan adanya suatu pesan tersendiri dan atau merupakan latar belakang budaya yang ada pada saat itu. Pendahuluan masjidmasjid di Indonesia sangat beragam bentuknya sesuai dengan waktu pendiriannya serta pemimpin yang menyebarkan Islam pada masa itu. Masa kejayaan Islam di Indonesia terutama di Pulau Jawa adalah semenjak adanya Walisongo. Walisongo inilah yang mulai mempelopori akulturasi budaya namun dengan metode yang berbeda-beda. Sebagian besar wali melakukan akulturasi melalui kesenian termasuk arsitektur bangunan.

Tinjaun kepustakaan Muhammad Nuruddin (2009) mendeskripsikan tentang "Tradisi Dandangan dan Buka Luwur diMasjid al-Aqsa Menara Kudus". Dalam pembahasan penelitiannya Nuruddin menjelaskan bahwa MAsjid al-Aqsha atau Mesjid Menara Kudus menjadi wadah berkembangnya beberapa budaya masyarakat yang mengitarinya. Tradisi Dandangan dan tradisi Buka Luwur adalah dua bentuk budaya yang berjalan di atas kenyataan Masjid Menara Kudus sebagai pusat peribadatan masyarakat. Nuruddin dalam penelitiannya mengungkapkan bahwa dua unsur budaya tersebut merupakan nilai tradisi yang telah lama dipraktekkan oleh Sunan Kudus. Penelitian 
Nuruddin tidak mengutip secara temporal kemunculan tradisi ini sebagai kesatuan budaya dari eksistensi Masjid Sunan Kudus.

Melihat beberapa deskripsi tinjauan kepustakaanyangtelahdirumuskandiatastampaklah bahwa penelitian ini merupakan penelitian baru. Usaha peneliti untuk mengungkapkan genealogi sejarah petilasan Suanan Kudus di Desa Jepang adalah kajian baru yang tidak pernah diteliti oleh peneliti lain. Pembacaan peneliti terhadap ruang dakwah Sunan Kudus di Desa Jepang Mejobo Kudus menyiratkan penelitian ini sebagai bagian dari pengungkapan sejarah dakwah.

\section{PEMBAHASAN}

\section{Petilasan sebagai Peninggalan Sejarah}

Mengamati dari sudut pandang kebahasaan, petilasan memiliki makna bekas peninggalan dan umumnya benda-benda yang bersejarah seperti istana, pekuburan. Petilasan ditinjau dari aspek etimologi berasal dari kata "tilas" yang bermakna bekas dari sesuatu pada masa lampau baik berupa bangunan atau benda-benda lainnya (Departemen Pendidikan Nasional, 2008: 1462). Dari landasan argumentatifini dapat dirangkaikan bahwa deskripsi tentang petilasan merupakan langkah analitis untuk menelusuri jejak-jejak sejarah yang telah lampau. Hal ini perlu diupayakan dengan pertimbangan etis sosial terhadap tuntutan yang dimandatkan kepada para akademisi guna mendeskripsikan peristiwa sejarah sebagai pembelajaran bagi masa yang akan datang.

Dalam lintasan sejarah manusia, berbagai peninggalan sejarah sebagai bukti petilasan dapat dijumpai di banyak tempat. Fakta ini dapat dihubungkan dengan sejarah panjang hadirnya ajaran Islam di tanah Jawa yang bersandar kepada beberapa situs sejarah yang telah ditinggalkan oleh para pendahulunya. Ditinjau dari sudut pandang arkeologis sebagai bukti peninggalan tradisi Islam masa lalu. Kedatangan Islam di tanah Jawa dapat dilihat dari beberapa peninggalan kesejarahan di dalamnya. Hal itu bisa dilihat dari peninggalan berupa makam, masjid, ragam hias, dan tata kota. Sebagai bukti faktual peninggalan Islam di tanah Jawa dalam catatan Anasom adalah ditemukannya Batu Nisan Kubur Fatimah Binti Maemun di Leran Gresik yang berangka tahun $475 \mathrm{H}$ (1082 M) (Amin, ed., 2002: 28-29).

Sementara itu, pada bagian petilasan sejarah Islam di Jawa melalui masjid, terdapat beberapa :
Islam Kuno menjadi bagian keberislamannya. Hal itu bisa disebutkan dengan berdirinya Masjid Agung Demak bersambung kuat dengan kebesaran Kerajaan Islam Demak pada akhir abad ke-15 sampai abad ke-16 (Yatim, 2001: 210-211). Untuk selanjutnya, petilasan lain dari kebesaran Islam Jawa di masa lalu adalah berdirinyaMasjid al-Aqsa atau Al-Manar yang terdapat di kawasan Kauman tepatnya daerah Kudus Kulon, Kota Kudus. Sebagaimana dijelaskan oleh Ricklefs, masjid tersebut bertarikh berdirinya pada tahun $956 \mathrm{H}(1549 \mathrm{M})$ yang dipahatkan di atas mihrab (Ricklefs, 2001: 94). Sunan Kudus sebagai tokoh utama dalam pembangunan masjid sebelum keberpindahannya ke Kota Kudus dijelaskan oleh Ricklefs sebagai imam Masjid Demak yang kelima dan pemimpin utama penyerangan tahun 1527 terhadap "Majapahit" (Ricklefs, 2001: 94).

Analisa terhadap sejarah petilasan masa lalu juga terlihat dari keberadaan Masjid Wali AlMa’mur Desa Jepang, sebagai salah satu peninggalan : masa lampau, keberadaan masjid ini diakui memiliki keterhubungan kuat dengan keberadaan Masjid Menara Kudus. Dalam suatu hikayat diceritakan bahwa Adipati Jipang Panolan alias Raden Arya Penangsang salah seorang tokoh yang berperan utama atas pembangunan masjid tersebut (Andrik, 2012: 63). Arya Penangsang dalam catatan sejarah disebutkan sebagai adipati yang berkuasa di sekitar kawasan Kerajaan Islam Demak. Di masa pemerintahan Sunan Prawoto sepeninggal Sultan Trenggono setelah penyerbuannya ke Blambangan pada tahun 1546, terjadi banyak pemberontakan yang dilakukan oleh adipati-adipati sekitar Kerajaan Demak. Sunan Prawoto sendiri kemudian dibunuh oleh Arya Penangsang sebagai Adipati Jipang Panolan pada tahun 1549 (Yatim, 2001: 212). Berdasar titik sejarah inilah, maka dapat diungkap sepenuhnya bahwa petilasan Masjid Wali AlMa’mur Desa Jepang sebagai salah satu kebanggaan masyarakat Desa Jepang merupakan peninggalan Arya Penangsang salah seorang murid kinasih dari Sunan Kudus. Kejadian ini berjalan di deretan sekitar tahun 1549 M atau di abad ke-16.

\section{Ruang Dakwah Sunan Kudus di Masjid Wali Al- Ma'mur \\ Desa Jepang Mejobo Kudus}

Mendeskripsikan secara detail tentang rentang waktu perjalanan sejarah di suatu komunitas tentunya sangatlah menyulitkan. Hal ini berpijak kepada kenyataan sejarah yang selalu bergerak 
dinamis untuk mendeskripsikan kejadian-kejadian masa lalu yang tidak terdokumentasi dengan baik. Kenyataan masa lalu yang masih berpijak kepada realitas tradisional masyarakatnya menjadi sebagian alasan untuk menyajikan data sejarah dengan akurasi yang memadai. Di atas kenyataan tersebut, beberapa deskripsi berikut akan menjelaskan reka sejarah dakwah Sunan Kudus dalam kehidupan masyarakat Desa Jepang Mejobo Kudus.

\section{Akulturasi Budaya Jawa dan Islam melalui Gapura Padureksa}

Melihat keutuhan Masjid Wali Desa Jepang atau masyarakat lebih mengenalnya dengan istilah MasjidAl-Ma'mur tidak bisa dilepaskan dengan bangunan-bangunan yang terdapat di sekitarnya. Salah satu bangunan yang menjadi unsur kesatuan dari Masjid Wali adalah Gapura Padureksa. Gapura Padureksa pada dasarnya merupakan pagar depan yang memagari kawasan Masjid Wali Al-Ma'mur. Dari bentuk awalnya, Gapura Padureksa berbentuk memanjang dari batas selatan sampai utara masjid.

Keberadaan Gapura Padureksa dalam kaitannya dengan Masjid Wali Al-Ma'mur Desa Jepang sangatlah berhubungan erat. Bentuknya yang memagari depan masjid membuktikan bahwa gapura tersebut menjadi bagian tidak terpisahkan dari berdirinya masjid. Hal ini secara niscaya dapat diamati secara mendasar dari beberapa desain masjid kuno di Jawa yang tiada menghilangkan unsur pagar masjid sebagai struktur arsitekturalnya (Tjandrasasmita, 2009: 7). Bentuk pagar yang menyerupai candi-candi peninggalan masyarakat Hindu tampak jelas pada bangunan gapura. Hal ini menunjukkan akulturasi yang dilakukan oleh Sunan Kudus pada proses islamisasi di Desa Jepang Mejobo Kudus sangat kuat dan dipertaruhkan.

Struktur bangunan Gapura Padureksa yang terdapat di bagian depan Masjid Wali Al-Ma’mur Desa Jepang menjadi bukti kuat bahwa akulturasi budaya masa lampau menjadi strategi yang baik untuk menarik kesadaran masyarakat atas agama Islam yang baru datang di tengah kehidupan mereka. Menguatkan islamisasi yang terjadi di Desa Jepang Uka Tjandrasasmita merumuskan bahwa arkeologi kewilayahan menjadi deskripsi yang bisa dijadikan tolak ukur dalam pengungkapan realitas keberagamaan (Tjandrasasmita, 2009: 6). Dalam hal ini Uka Tjandrasasmita menjelaskan bahwa menggunakan pendekatan arkeologis dalam penelitian sejarah keagamaan sangatlah penting.
Eksplorasi bergambar atas Masjid Jepara pada abad ke-17 dan Masjid Agung Banten pada awal abad ke19, mengukuhkan bahwa eksistensi pagar masjid menjadi bagian tidak terpisahkan dari bangunan masjid.

Pada bagian yang berbeda, sebagaimana catatan Ricklefs tentang Masjid Menara Kudus atau yang dikenal dengan sebutan al-Manar atau al-Aqsa (seperti Masjid Yerussalem) bertarikh tahun $956 \mathrm{H}(1549 \mathrm{M})$ yang dipahatkan di atas mihrab (relung yang menunjukkan arah Mekah bagi orang yang salat), menunjukkan keutuhan masjid tersebut dengan pemagaran yang terdapat di depan masjid (Ricklefs, 2001: 93-94). Di atas simbolisasi pemagaran masjid pada beberapa masjid kuno yang terdapat di Jawa, maka Gapura Padureksa sebagai kesatuan dari Masjid Wali Al-Ma’mur merupakan arsitektur kesatuannya.

Keberadaan Gapura Padureksa sebagai kesatuan ornamen atas Masjid Wali Al-Ma'mur Desa Jepang mengukuhkan simbolisasi bangunan masjid Islam kuno di Jawa. Beberapa masjid yang bisa dijumpai di Jawa mengadopsi aneka arsitektur dengan tradisi Hindu-Buddha yang telah berkembang lama sebelum kedatangan Islam. Hal ini tentunya tidak dapat dinafikan karena keberadaannya sebagai upaya besar untuk membangun harmoni lingkungan dan diterimanya ajaran Islam yang baru datang tersebut dengan lapang tanpa penolakan.

\section{Islamitas Tradisi Rebo Wekasan}

Masyarakat Desa Jepang memiliki keyakinan kuat bahwa Masjid Wali Al-Ma'mur memiliki keunikan tersendiri bagi orang-orang yang datang untuk mengunjunginya. Keunikan tersebut berdasar kepada kenyataan dari masjid tersebut yang masih memiliki ornamen kuno dan masih bisa dinikmati. Kenyataan tersebut juga berjalan secara berjajar dengan hikayat-hikayat mistis yang disampaikan oleh para penutur sejarah yang ada di dalamnya;

"Saking cerita sesepuh rumiyen niku mas, tiang ingkang lewat saking ngajeng gapura lan ngagem caping, maka caping niku bakal kantil. Lajeng tiang ingkang naik motor lan ngebut niku iso keblusuk".

Dari cerita para sesepuh terdahulu mas, orang yang lewat depan gapura menggunakan caping, maka dipercayai caping itu akan lekat di kepala. Selanjutnya, orang-orang yang berani naik motor dengan mengebut maka dia bisa terjatuh (wawancara Mbah Kamsin. pengurus Masjid Wali Desa Jepang, 
19/7/2012).

Dahulu kala, ketika saya masih kanak-kanak, saya sering melempar uang koin ratusan guna meminta terkabulnya hajat. Hal ini banyak dilakukan oleh anak-anak kecil seumuran saya di masanya (wawancara Mastur Ketua Ta'mir Masjid Wali Al-Ma'mur, 19/6/2012) (data ini diperoleh setelah melakukan rapat bersama (Focus Group Discussion) tentang eksistensi Masjid Wali Al-Ma'mur Desa Jepang).

Beberapa argumentasi yang dinyatakan oleh para penutur sejarah di atas menunjukkan bahwa eksistensi kekeramatan Masjid Wali Al-Ma'mur dan Gapura Padureksa yang terdapat di bagian depan masjid mengandung alasan yang saling menguatkan. Keangkeran Masjid Wali Al-Ma'mur yang banyak diyakini oleh masyarakat Desa Jepang sangat berdasar dengan persepsi yang dibangun oleh Juru Kunci Masjid. Letak kuburan yang terdapat di belakang masjid, semakin menambah daya mistis masjid ini dibandingkan dengan bentuk masjid terkini. Sebagaimana juga dituturkan oleh para sesepuh masjid, pelebaran tempat di sekitar masjid memindah beberapa makam para leluhur desa yang terdapat di bagian utara masjid.

Keunikan cerita lain yang disampaikan oleh para penutur sejarah atas Masjid Wali AlMa'mur adalah ketakutan masyarakat di masa lalu untuk menginap di dalam masjid. Fakta ini disampaikan oleh Bapak Kepala Desa bahwa dari cerita para sesepuh di masa lalu meneguhkan ketakutan masyarakat untuk berdiam di masjid pada waktu malam hari. Kenyataan ini pula diamini sepenuhnya oleh Bapak Suparno bahwa keberadaan Mbah Kamsin sebagai Juru Kunci masjid yang telah berjalan sebanyak tiga keturunan dari atasnya juga tiada berkenan untuk diganti meskipun kondisi dirinya yang sudah tua renta.

"Kami para pengurus pernah mengusulkan untuk mengganti Mbah Kamsin sebagai Juru Kunci Masjid namun tetap memberikan tunjangan padanya. Ternyata, beliau menjawab, "Siapa berani menggantikan saya, akan saya sampaikan kepada leluhur yang telah membangun masjid" (wawancara Suparno- Pengurus Masjid Wali Al-Ma’mur, 19/6/2012)".

Kesungguhan yang disampaikan oleh Mbah Kamsin untuk tetap menjadi Juru Kunci Masjid Wali Al-Ma'mur membuktikan bahwa kenyataan dirinya ingin diabdikan sepenuhnya untuk kemakmuran masjid. Tidak tanggung-tanggung pula, hampir setiap pagi hari, membersihkan makam yang terdapat di belakang masjid dilakukannya sebagai kesatuan pesan yang pernah disampaikan oleh Habib Lutfi dari Pekalongan.

Keangkeran yang menjadi bagian tidak terpisahkan dari keunikan Masjid Wali AlMa’mur pada kenyataannya telah diperjuangkan penafiannya oleh salah seorang tokoh penting dari perwujudan masjid wali terkini. Sayyid Ndara Ali bernama lengkap Habib Syekh Ali Al-Idrus diyakini oleh masyarakat sebagai tokoh yang telah mengubah paradigma mindset lama masyarakat dari kondisi angker masjid menjadi lebih makmur dan bermanfaat. Salah satu usaha yang dilakukan oleh Sayyid Ndara Ali adalah melakukan seremonial haflah Hari Rabu terakhir Rebo Wekasan dari Bulan Shafar tahun Hijriyah. Sebagaimana dinyatakan oleh Andrik bahwa istilah Rebo Wekasan diambil dari Bahasa Jawa Rebo yang berarti hari Rabu, sedangkan Wekasan merupakan sinonim dari pungkasan yang dalam Bahasa Indonesia berarti terakhir (Andrik, 2012: 61).

Tradisi Rebo Wekasan tercatat sebagai bagian dari tradisi yang dilanjutkan oleh Sayyid Ndara Ali seraya melanjutkan perjuangan dakwah di Masjid Wali Al-Ma'mur Desa Jepang. Sebagaimana tercatat dalam Buku Panduan Kegiatan Budaya Tradisi Rebo Wekasan dijelaskan di dalamnya bahwa Sayyid Ndara Ali berdomisili di Desa Karangmalang, Kecamatan Gebog, Kabupaten Kudus. Usaha untuk memakmurkan Masjid Wali Al-Ma'mur Desa Jepang dilakukannya dengan senantiasa berkunjung ke masjid ini untuk mengajarkan ilmu agama (AlQur'an dan Ilmu Fikih) dan juga mengajarkan kesenian dan tradisi (seperti musik lesung untuk perempuan dan rebana untuk laki-laki) (Dokumen Masjid Jami’ Al-Ma'mur, 2011).

Ditinjau dari asal dan usul tradisi Rebo Wekasan, masyarakat Desa Jepang sepakat bahwa ritual ini mulai semarak perkembangannya pada masa kehadiran Sayyid Ndara Ali. Kehadiran Sayyid Ndara Ali untuk memakmurkan Masjid Wali Desa Jepang sama halnya dengan usaha yang dilakukan oleh Suanan Kudus dengan membangun masjid ini sebagai salah satu tempat singgah selain Masjid Menara Kudus. Kehadiran Sayyid Ndara Ali di Desa Jepang tepatnya di Masjid Wali Al-Ma'mur mengukuhkan dirinya sebagai dai yang ingin menyebarkan ajaran Islam di luar tempat tinggalnya. Domisili Sayyid Ndara Ali di Desa Karangmalang, Kecamatan Gebog, Kabupaten Kudus menjadi dasar 
petunjuk bahwa aktivitas berdakwah yang diteladani dari para ulama' terdahulu mengilhami dirinya.

Untuk selanjutnya, catatan masyarakat (Dokumen Masjid Jami’ Al-Ma’mur, 2011) bahwa aktivitas Rebo Wekasan yang mulai dilakukan dengan ritual-ritual keberagamaan, seperti kirab jajanan yang terdiri dari kue apem, bikang, dan hasil bumi (Lihat, Andrik, 2012: 62) terjadi sejak awal abad ke-20. Hal ini menjadi dasar pembukti bahwa kehadiran Sayyid Ndara Ali di Masjid Wali Al-Ma'mur sejalur tahun dengan pemugaran masjid sebagaimana tercatat dalam Prasasti Masjid Wali Al-Ma'mur yang terpampang dengan jelas di sebelah kiri atas mihrab; "Iki Jenenge Masjid AlMa'mur. InsyaAllah sopo-sopo wonge sodaqoh ring masjid iki selamet dunyu akherat. Dadine iki masjid tanggal 16 Muharram sanah/tahun $1336 \mathrm{H}$. tahun Wuulanda 1917 M" (Ini masjid namanya Al-Ma’mur. InsyaAllah siapa saja yang bersedekah untuk masjid ini akan selamat dunia akhirat. Jadinya masjid ini tanggal, 16 Muharram tahun $1336 \mathrm{H}$. tahun Belanda 1917 M).

\section{Representasi Air Salamun (Keselamatan)}

Kehadiran tradisi Rebo Wekasan dalam keberagamaan masyarakat Desa Jepang tidak bisa dilepaskan dari pengakuan masyarakat akan eksistensi Sumur Masjid Wali Al-Ma’mur. Keberadaan Sumur Masjid Wali Al-Ma’mur Desa Jepang diyakini oleh masyarakat sebagai sumur bertuah yang mengandung keberkahan bagi pribadi yang meminumnya. Sebagaimana dicatat oleh Andrik bahwa awal keberadaan sumur ini tercipta melalui penancapan tongkat Sunan Kudus. Andrik menjelaskan bahwa ketika hari Selasa malam Rabu terakhir di Bulan Shafar saat adzan Maghrib dikumandangkan, debit air sumur bertambah sehingga air terlihat melimpah. Pengambilan air dari Sumur Masjid Wali Al-Ma'mur Desa Jepang merupakan acara inti dari ritual Rebo Wekasan (Andrik, 2012: 62).

Rangkaian kegiatan Rebo Wekasan yang diisi dengan acara inti pengambilan air Sumur Masjid Wali Al-Ma'mur Desa Jepang dilangsungkan pada bulan Shafar. Agus Yusrun Nafi' mencatat bahwa Shafar (Sapar dalam bahasa Jawa) adalah bulan kedua dalam penanggalan Hijriyah. Dalam pandangan Agus Yusrun Nafi' dikukuhkan bahwa sebagian ulama menyebut bulan ini dengan istilah Shofarul Khoir, artinya bulan Safar yang penuh kebaikan. Ada alasan menamai seperti itu karena dulu banyak orang meyakini bahwa itu bulan sial atau penuh bala (bencana) (Agus Yusrun Nafi, "Kearifan Rebo Wekasan" dalam http://suaramerdeka.com/ v1/index.php/read/cetak/2012/02/03/175875/ Kearifan-Rebo-Wekasan, diakses 5/5/2012).

Kehadiran ritual Rebo Wekasan yang dilanjutkan dengan pengambilan Air Keselamatan (Salamun) yang dilakukan oleh masyarakat Desa Jepang tidak berbeda jauh dengan tradisi-tradisi lain yang terdapat di tengah-tengah kehidupan masyarakat Jawa pada umumnya. Hal ini dapat dilihat dari representasi tradisi Dandangan dan Buka Luwur sebagai kesatuan tradisi yang melekat pada Masjid Menara Kudus (Nuruddin, 2009: 210216). Di dua tradisi yang melekat dengan kebesaran Masjid Menara Kudus, masyarakat memiliki keyakinan kuat akan nilai-nilai luhur yang ada pada kedua tradisi tersebut. Sebagaimana pula dengan keyakinan yang terbangun dalam diri masyarakat atas kenyataan dua tradisi budaya tersebut, masyarakat Desa Jepang berkeyakinan penuh pula bahwa tradisi Rebo Wekasan yang diisi pula dengan pengambilan Air Keselamatan (Salamun) bermuatan nilai-nilai luhur pendahulunya.

Dalam perkembangannya, warga Desa Jepang menyelenggarakan acara Rebo Wekasan, mengisinya dengan khatam Al-Qur'an dan beberapa ritual lainnya, seperti doa, minum air azimat (Salamun), selamatan, dan salat sunat (Dokumen Masjid Jami' Al-Ma'mur, 2011: 4-5). Rangkaian dari beberapa ritual yang melekat pada tradisi Rebo Wekasan tersebut merupakan upaya besar masyarakat untuk menghindari tertimpanya 320 ribu macam bencana yang diyakini oleh masyarakat Islam Jawa diturunkan pada Hari Rabu terakhir di bulan Shafar. Andrik mencatat, berdasar dari keyakinan umum masyarakat Desa Jepang, pada malam Rabu terakhir bulan Shafar, Allah menurunkan 320 ribu bencana (balak). Untuk menghindari balak tersebut perlu diadakan doa agar setiap pribadi bisa terhindar dari ketertimpaannya. Dalam keyakinan masyarakat Desa Jepang, yakni mengadakan doa pada malam Rabu terakhir di bulan Shafar (Andrik, 2012: 62).

Sebagai salah satu rangkaian acara dalam ritual Rebo Wekasan, minum Air Azimat/Keselamatan (Salamun) menjadi acara utama yang diikuti oleh masyarakat. Hal ini dilakukan setelah pelaksanaan kirab jajanan dan hasil bumi yang dilakukan pada saat siang sampai menjelang malam. Agus Yusrun Nafi' menegaskan, setelah Shalat Magrib, takmir membagikan Air Keselamatan (Salamun) kepada jamaah atau orang yang membutuhkan. Air yang dibagikan tahun ini adalah adalah air 
yang diberi doa pada tahun lalu. Air yang diberi doa oleh tokoh ulama pada 17 Januari 2012, akan dibagikan ke masyarakat pada 2013, atau setahun kemudian. Untuk selanjutnya, dalam catatan Agus Yusrun Nafi' ditegaskan bahwa masyarakat kini memaknai secara cerdas peringatan Rebo Wekasan untuk kembali mengenang perjuangan para ulama yang menyebarkan Islam di desa tersebut, sekaligus menggali nilai kearifan local (Agus Yusrun Nafi', "Kearifan Rebo Wekasan" dalam http://suaramerdeka.com/v1/index.php/read/ cetak/2012/02/03/175875/Kearifan Rebo-Wekasan, diakses 5/5/2012). Menurut Agus, memanfaatkan budaya Rebo Wekasan dengan memformatnya sebagai tradisi haul (Departemen Pendidikan Nasional, 2008: 488) adalah langkah ijtihad para ulama di Desa Jepang untuk menghadapi kekinian budaya. Hipotesa yang dinyatakan oleh Agus Yusrun Nafi' tersebut merupakan dasar berpijak bahwa secara eksistensial, kehadiran tradisi Rebo Wekasan merupakan kearifan lokal yang niscaya lestari.

Pengambilan Air Keselamatan (Salamun) yang diberikan kepada masyarakat sebagai rangkaian ritual dalam tradisi Rebo Wekasan memberi keyakinan tersendiri bagi masyarakat Desa Jepang. Penggunaan istilah "Air Keselamatan (Salamun)" dalam penyebutan Air Azimat tersebut bersandar kepada keyakinan masyarakat bahwa kata Salamun adalah kenyataan yang akan memberikan keselamatan di atas turunnya 320 ribu bencana yang diturunkan oleh Allah swt., pada Hari Rabu terakhir di Bulan Shafar. Pengurus Masjid Jami' Al-Ma'mur bersama Pemerintah Desa Jepang serta Dinas Kebudayaan dan Pariwisata Kabupaten Kudus dalam Buku Panduan Kegiatan Budaya Tradisi Rebo Wekasan di Masjid Jami' Al-Ma'mur Desa Jepang Kecamatan Mejobo, Kabupaten Kudus 2011 menyimpulkan bahwa telah disebutkan dalam Kitab Nihayatuz Zain karya Imam Nawawi Al-Jawi Al-Bantani sebagai penjelasan atas matan Kitab Fikih Qurratul 'Ain "Barangsiapa yang menulis tujuh ayat Salaamah, yaitu tujuh ayat al-Qur'an yang diawali dengan lafal Salaamun, maka baginya keselamatan" (Dokumen Masjid Jami’ Al-Ma’mur, 2011:4). Adapun ketujuh ayat al-Qur'an tersebut sebagai berikut:

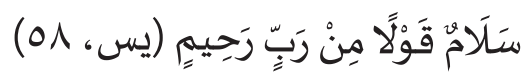

Artinya: (Kepada mereka dikatakan): "Salam", sebagai ucapan selamat dari Tuhan Yang Maha Penyayang (QS., Yasin, 36:58) (Departemen Agama Republik Indonesia, 1993:712).

$$
\text { سََلَامُ عَلَى نُوحِ فِي الْعَالَمِينَ (الصافات، V9) }
$$

Artinya: Kesejahteraan dilimpahkan atas Nuh di seluruh alam (QS., Ash-Shaffat, 37:79) (Departemen Agama Republik Indonesia, 1993:725).

$$
\text { سَالَمُ عَلَى إِبْرَاهِيمَ (الصيافات، } 9 \text {. } 1 \text { ) }
$$

Artinya: (Yaitu) "Kesejahteraan dilimpahkan atas Ibrahim (QS., Ash-Shaffat, 37:109) (Departemen Agama Republik Indonesia, 1993:726)

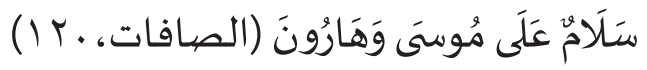

Artinya: (Yaitu) kesejahteraan dilimpahkan atas Musa dan Harun (QS., Ash-Shaffat, 37:120) (Departemen Agama Republik Indonesia, 1993:726).

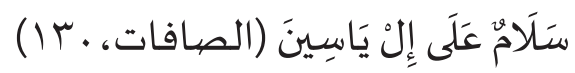

Artinya: (Yaitu) kesejahteraan dilimpahkan atas Ilyas? (QS., Ash-Shaffat, 37:130) (Departemen Agama Republik Indonesia, 1993:727).

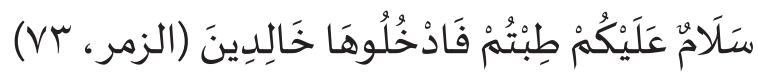

Artinya: "Kesejahteraan (dilimpahkan) atasmu, Berbahagialah kamu! Maka masukilah surga ini, sedang kamu kekal di dalamnya (QS., AzZumar, 39:73) (Departemen Agama Republik Indonesia, 1993:756).

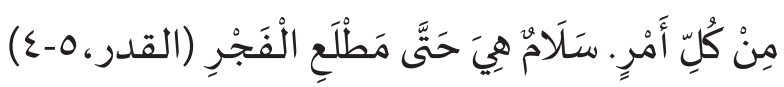

Artinya: Untuk mengatur segala urusan. Malam itu (penuh) kesejahteraan sampai terbit fajar (QS., Al-Qadar, 97:4-5) (Departemen Agama Republik Indonesia, 1993:1082).

Ketujuh ayat al-Qur'an di atas ditulis di atas kertas kemudian direndam ke dalam air yang telah diambil dari Sumur Masjid Wali Al-Ma’mur Desa Jepang. Setelah terendamnya tulisan dalam air tersebut, maka air yang telah diambil dari Sumur Masjid Wali Al-Ma’mur Desa Jepang diyakini mengandung unsur keselamatan di dalamnya.

\section{PENUTUP}

Masjid Wali Al-Ma’mur dapat dijelaskan pembangunannya searah waktu berdirinya 
Masjid Menara Kudus dengan pelaku sejarahnya Arya Penangsang Adipati Jipang Panolan. Arya Penangsang adalah salah seorang adipati yang melakukan pemberontakan terhadap Kerajaan Demak pada tahun 1549 M yang kala itu digantikan oleh Sunan Prawoto adik kandung dari Sultan Trenggono. Arya Penangsang pada titik ini menjadi pijakan utama untuk merunut sepenuhnya genealogi kesejarahan dari Masjid Wali Al-Mảmur Desa Jepang.

Untuk selanjutnya, bentuk ruang dakwah Sunan Kudus di Desa Jepang Mejobo Kudus dapat terlihat pada akulturasi budaya Jawa dan Islam. Hal ini terlihat pada bangunan Gapura Padureksa yang terdapat di bagian depan pagar masjid. Gapura tersebut menyiratkan akulturasi budaya masyarakat Hindu Budha terhadap budaya Islam. Syiar ini dilakukan oleh Sunan Kudus untuk memasyarakatkan Islam dalam kehidupan sosial keagamaan masyarakat. Dari berdirinya Masjid Wali Al-Ma'mur Desa Jepang, masyarakat memperoleh beberapa unsur budaya islami yang ditinggalkan oleh Sunan Kudus. Seremonial Rebo Wekasan Hari Rabu terakhir dari Bulan Shafar dengan penyatuan seromial pengambilan air keselamatan (Air Salamun), adalah kearifan budaya yang ditinggalkan Sunan di tengah-tengah keberagamaan masyarakat Desa Jepang.

\section{UCAPAN TERIMA KASIH}

Hasil penelitian ini secara niscaya masih perlu penyempurnaan. Garapan penelitian yang perlu dibahas di bagian lain adalah pengungkapan pola-pola keagamaan masyarakat yang telah dikembangkan oleh Suanan Kudus pada awal dakwahnya di Kabupaten Kudus secara umum dan Desa Jepang Mejobo secara khusus. Namun, di atas semua kekurangan sebagai kelanjutan dari usaha penelitian, penelitian ini secara hakiki dapat dijadikan landasan akademis untuk penelitian selanjutnya. Untuk itulah, ucapan terima kasih disampaikan setinggi-tingginya kepada Ketua Sekolah Tinggi Agama Islam Negeri (STAIN) Kudus dan Kepala Pusat Penelitian dan Pengabdian kepada Masyarakat (P3M) STAIN Kudus yang telah memberikan kesempatan kepada penulis melakukan penelitian ini.

\section{DAFTAR PUSTAKA}

Al-Qur'an dan Terjemahannya. 1993. Departemen Agama Republik Indonesia.

Amien, Darori. 2002. Islam dan kebudayaan Jawa. 2002. Yogyakarta: Gamamedia.

Andrik. 2012. 'Tolak Balak Melalui Ritual Rebo Wekasan'. Paradigma 02/21.

Departemen Pendidikan Nasional. 2008. Kamus Besar Bahasa Indonesia Pusat Bahasa; Edisi Keempat. Jakarta: Gramedia.

Lombard, Denys. 2005. Nusa Jawa: Silang Budaya Jaringan Asia. Jilid, II, terj., Winarsih Partaningrat Arifin dkk. Jakarta: Gramedia.

Nafi', Agus Yusrun. 2012. 'Kearifan Rebo Wekasan' dalam http://suaramerdeka.com/v1/index. $\mathrm{php} / \mathrm{read} / \mathrm{cetak} / 2012 / 02 / 03 / 175875 /$ Kearifan-Rebo-Wekasan, diakses 5/5/2012.

Nagazumi, Akira. 1998. 'Historical Studies'. Bijdragen tot de Taal-, Land-en Volkenkunde 144/2-3.

Nuruddin, Muhammad. 2009. 'Tradisi Dandangan dan Buka Luwur di Masjid al-Aqsa Menara Kudus. Tsaqafiyyat 10/2.

Pengurus Masjid Jami' Al-Ma’mur bersama Pemerintah Desa Jepang serta Dinas Kebudayaan dan Pariwisata Kabupaten Kudus. 2011. Buku Panduan Kegiatan Budaya Tradisi Rebo Wekasan di Masjid Jami' AlMa'mur Desa Jepang Kecamatan Mejobo, Kabupaten Kudus.

Ricklefs, M.C. 2001. Sejarah Indonesia Modern 12002004 (Tej) Satrio Wahono. Jakarta: Serambi Ilmu Semesta.

Supriyadi, Bambang. 2010. 'Kajian Ornamen pada Masjid Bersejarah Kawasan Pantura Jawa Tengan'. Skripsi. UNDIP.

Tjandrasasmita, Uka. 2009. Arkeologi Islam Nusantara. Jakarta: KPG.

Van Dijk, Kees dan P. Nas. 1998. 'Dakwah and Indigenous Culture; The Dissemination of Islam' dalam Bijdragen tot de Taal-, Land- en Volkenkunde, Globalization, Localization and Indonesia, 154/2.

Windarti, Sri Sari. 2010. 'Peran Masjid Menara Kudus Bagi Wisatawan, Masyarakat Sekitar dan Pendidikan Generasi Muda. Skripsi, Universitas Negeri Semarang.

Yatim, Badri. 2001. Sejarah Peradaban Islam. Jakarta: Raja Grafindo Persada. 